\title{
PENGAKUAN EKS PARASIT LAJANG KARYA AYU UTAMI BERDASARKAN PERSPEKTIF JUNG
}

\author{
Khoirun Nisak \\ SMK N 2 Sukorejo \\ Jl. Raya Sukorejo-Bangil Km.2 Lecari Sukorejo, Pasuruan, Indonesia \\ Pos-el: nisakdf@gmail.com
}

\begin{abstract}
This research aims to obtain a description of objectively the dynamics of the main figure in the perspective Jung based on personality which is in novel "Pengakuan Eks Parasit Lajang" creation Ayu Utami. This study using the qualitative research with the hermeneutic and researchers as a key metric. assisted by gathering data. Data is collected from unit-unit the text which reflect the majority of dynamics in the relationship between the personality of top leaders of the banned in a novel "Pengakuan Eks Parasit Lajang" creation Ayu Utami. The internal factors encourage the dynamics of personality the main figure is psychic energy (the libido) of encouragement (drive) and volition (will) that is spatially dynamic and work simultaneously to wholeness personal. External factors that encourage the dynamics of personality the main figure is the environment social the main figure in especially factors social environment primary namely figure family .
\end{abstract}

Keywords : Personality the dynamics of personality

\begin{abstract}
Abstrak
Penelitian ini bertujuan untuk memperoleh deskripsi secara objektif tentang "dinamika kepribadian tokoh utama berdasarkan perspektif Jung" yang ada dalam novel "Pengakuan Eks Parasit Lajang Karya Ayu Utami". Penelitian ini menggunakan rancangan penelitian kualitatif dengan metode hermeneutik dan peneliti sebagai instrumen kunci dibantu dengan metrik penjaringan data. Data diperoleh dari unit-unit teks yang mencerminkan penggambaraan dinamika kepribadian tokoh utama dalam novel "Pengakuan Eks Parasit Lajang Karya Ayu Utami" Faktor internal yang menjadi pendorong dinamika kepribadian tokoh utama adalah energi psikis (libido) berupa dorongan (drive) dan kemauan (will) yang bersifat dinamis dan bekerja secara simultan menuju keutuhan pribadi. Faktor eksternal yang menjadi pendorong dinamika kepribadian tokoh utama adalah lingkungan sosial tokoh utama terutama faktor lingkungan sosial primer yaitu figur keluarga.
\end{abstract}


Kata kunci: kepribadian, dinamika kepribadian

\section{PENDAHULUAN}

Sastra adalah tiruan kehidupan (imitation of life), sehingga terdapat kaitan yang erat antara dunia sastra dan realitas kehidupan. Banyak karya sastra yang diangkat dari kehidupan nyata, baik yang dialami sendiri oleh pengarangnya maupun kehidupan orang-orang yang ada di lingkungan sekitarnya. Purba (2010:3) mengatakan bahwa sastra merupakan sebuah ciptaan, kreasi, bukan semata-mata imitasi, sebuah cabang seni, sebuah karya imajinatif yang berkaitan erat dengan semua aspek manusia dan alam dengan keseluruhannya.

Sesuai dengan hakikatnya sebagai karya seni yang imajintif, karya sastra bertujuan untuk memberikan pemahaman terhadap masyarakat secara tidak langsung. Pemahaman tersebut dapat diperoleh melalui usaha membaca dengan sungguh-sungguh dan mencari makna yang tersembunyi di balik teks sastra. Untuk menggali makna yang terkandung dalam karya sastra diperlukan pengkajian yang mendalam terhadap aspekaspek tertentu yang dianggap penting untuk diangkat, sehingga tercapai tujuan penulisan karya sastra.

Salah satu aspek yang perlu mendapat perhatian untuk dikaji dalam karya sastra adalah aspek psikologi. Pengkajian aspek psikilogis dalam karya sastra penting dilakukan karena relevansinya dengan problemtika masyarakat modern dewasa ini yang cenderung hanya mementingkan kehidupan duniawi (profan) dan serba materialistis. Ratna (2013:342-343) mengungkapkan bahwa relevansi analisis psikologis diperlukan justru pada saat tingkat peradaban mencapai kemajuan, pada saat manusia kehilangan pengendalian psikologis. Kemajuan teknologi mengandung aspek-aspek negatif, misalnya, hilangnya harga diri sebagai akibat hampir keseluruhan harapan dialihkan pada teknologi, pada mesin dengan berbagai mekanismenya. Psikologi, khususnya psikologi analitik, diharapkan mampu untuk menemukan aspek-aspek ketidaksadaran yang diduga merupakan sumber-sumber penyimpangan psikologis sekaligus dengan terapi-terapinnya.

Pengkajian terhadap aspek psikologis dalam karya sastra melibatkan unsur intrinsik sastra, khususnya tokoh dan penokohan. 
Tokoh dalam karya sastra adalah manusia, atau dapat juga disebut sebagai sesuatu yang dimanusiakan, yang memiliki kepribadian tertentu. Kepribadian yang diemban oleh tokoh dalam karya sastra itu akan berimpitan dengan hukum-hukum atau teori-teori psikologi tertentu. Dengan demikian, sastra sebagai gejala kejiwaan yang mengandung fenomena-fenomena kejiwaan yang tampak dari tingkah laku tokohtokohnya dapat dikaji dengan menggunakan pendekatan psikologi.

Dilihat dari proses penciptaan karya sastra, Wellek dan Warren (2014:106) mengungkapkan bahwa terkadang ada teori psikologi tertentu yang dianut oleh pengarang, baik secara sadar atau samar-samar, dan teori tersebut ternyata cocok untuk menjelaskan tokoh-tokoh dan situasi cerita. Eksplorasi teori psikologi dalam penciptaan sastra ini akan menambah nilai artistik karena menunjang koherensi dan kompleksitas karya. Hal ini mengisyaratkan bahwa sebelum melakukan pengkajian aspek psikologis dalam karya sastra diperlukan pencermatan lebih dalam terhadap kemungkinan adanya teori psikologi tertentu yang melatarbelakangi penciptaan karya sastra itu sendiri. Ketepatan pemilihan teori psikologi diharapkan memberikan hasil analisis yang lebih tepat terhadap aspek psikologis dalam karya sastra yang dikaji.

Salah satu karya sastra kontemporer yang mengandung aspek psikologis adalah novel Pengakuan Eks Parasit Lajang karya Ayu Utami. Aspek psikologis dalam novel Pengakuan Eks Parasit Lajang tercermin pada kepribadian tokoh utama yang sarat dengan konflik batin. Novel ini menceritakan perjalanan hidup tokoh utama yaitu A yang berontak terhadap nilai-nilai kehidupan. Dia memutuskan untuk melepaskan keperawanannya di usia dua puluh, untuk sekaligus menghapus konsep keperawanan yang baginya tidak adil. Konsep keperawanan yang selalu dijadikan patokan laki-laki dalam menentukan kepantasan baginya untuk menikahi perempuan yang merupakan norma umum di masyarakat. Selama bertahun-tahun ia mencoba melawan nilai-nilai adat, agama, dan hukum yang patriarkal. Patriarkal atau partiarki merupakan sistem sosial yang menempatkan laki-laki sebagai sosok otoritas utama yang sentral dalam organisasi sosial (keluarga) namun tidak demikian dengan tokoh A. Dia menginginkan matriarkal lebih diakui di masyarakat. Untuk itu dia buktikan dengan sikapnya terhadap Nik kekasihnya bahwa dia dapat menguasai Nik tanpa harus masuk agama Nik. Tanpa disadari A larut dalam putaran batin yang pelik sampai pada titiknya dia menyadari 
bahwa patriarkal hanya merupakan kenyataan sejarah.

Berdasarkan fenomena psikis tokoh utama tersebut, teori psikologi yang relevan untuk pengkajian dinamika kepribadian tokoh utama novel Pengakuan Eks Parasit Lajang ini adalah psikologi analitis yang dikembangkan oleh Jung. Jung mengemukakan gagasan tentang pentingnya aspek ketidaksadaran, di samping kesadaran, dalam membentuk pribadi yang utuh. (Feist \& Feist, 2014:116).

Pentingnya penerapan teori psikologi analitis dalam pengkajian aspek psikologis juga diperkuat dengan pendapat Ratna (2013:344347) yang menegaskan bahwa dalam psikologi sastra, di samping memanfaatkan pengalaman sekarang, yang justru lebih penting adalah pengalaman kolektif dalam kaitannya dengan meterial filogenesis perkembangan evolusi spesies manusia.

\section{METODE PENELITIAN}

Menurut Ratna (2013:41) pendekatan dapat disejajarkan dengan bidang ilmu tertentu. Dalam penelitian ini digunakan pendekatan psikologi dengan mengacu pada teori psikologi analitis Jung. Jung mengemukkan gagasan tentang pentingnya aspek kesadaran, di samping ketidaksadaran, dalam membentuk pribadi yang utuh. Teori ini relevan dengan kondisi kepribadian tokoh utama novel Pengakuan Eks Parasit Lajang yang didominasi aspek kesadaran yaitu munculnya konflikkonflik batin dalam cerita kehidupannya.

Penelitian ini menggunakan rancangan penelitian kualitatif dengan metode hermeneutik. Ratna (2013:46) menggungkapkan bahwa dalam metode hermeneutik analisis data secara keseluruhan memanfaatkan penafsiran dengan menyajikannya dalam bentuk deskripsi. Lebih lanjut Santana (2010:189) menjelaskan bahwa deskripsi ialah penggunaan katakata untuk merekreasikan sebuah pengalaman, yang membuat pembaca dapat merasakannya (ikut melihat, mendengar, merasakan). Beberapa pendapat yang sifatnya teoritik mesti diuraikan dalam rumusan penjelasan yang definitif, melalui gambaran peristiwa yang dapat dikenali.

Sumber data penelitian dalam kajian ini adalah berupa unit-unit teks yang mencerminkan penggambaraan dinamika kepribadian tokoh utama dalam novel "Pengakuan Eks Parasit Lajang Karya Ayu Utami" terbitan KPG (Kepustakaan Populer Gramedia), cetakan kedua: Mei 2013. Data dapat diartikan sebagai bahan mentah yang diperoleh peneliti dari penelitiannya, bisa berupa fakta maupun keterangan yang dapat digunakan sebagai dasar analisis. Dalam penelitian ini data yang digunakan berupa unit-unit teks Khoirun Nisak, Variasi Bahasa. (16-28) 
atau kutipan-kutipan hasil dari pembacaan heuristik dan hermenuetika yang dijadikan sebagai ukuran dalam mengembangkan pengertian dan memberikan deskripsi yang benar terhadap unit-unit teks yang mencerminkan penggambaraan dinamika kepribadian tokoh utama dalam novel "Pengakuan Eks Parasit Lajang Karya Ayu Utami".

\section{HASIL DAN PEMBAHASAN}

Pada bagian disajiakn
temuan penelitian Dinamika Kepribadian Tokoh Utama Novel Pengakuan Eks Parasit Lajang Karya Ayu Utami Berdasarkan Perspektif Jung. Pembahasan tersebut meliputi: (1) faktor-faktor internal pendorong dinamika kepribadian tokoh utama, (2) faktorfaktor eksternal pendorong dinamika kepribadian tokoh utama.

\section{Faktor-Faktor Internal Pendorong Dinamika Kepribadian Tokoh Utama}

\section{1) Dorongan Ingin Tahu}

Novel Pengakuan Eks Parasit Lanjang bercerita tentang problema hidup dan konflik batin yang mewarnai dinamika kepribadian tokoh utama selama hidupnya. Masa kecil hingga remaja diceritakan dalam bentuk kilas balik dari ingatan masa lalu yang muncul saat kuliah di Universitas Indonesia jurusan Sastra Indonesia. Problema dan konflik batin tokoh utama A semakin kompleks dimulai pada usia duapuluh tahun karena di usia itulah dia melepas keperawanannya. Dinamika kepribadian tokoh A mengalami pasang surut karena kenyataan hidup tidak sejalan dengan konsep hidupnya terutama dalam hal seksualitas dan spiritualitas.

Uraian tersebut berkaitan dengan adanya dorongan dan kemauan dalam diri tokoh A yang dalam psikologi analitis Jung dikategorikan sebagai manifestasi dari energi psikis (libido). Energi psikis tersebut selanjutnya disebut sebagai faktor internal yang menjadi pendorong dinamika kepribadian karena bersumber dari dalam diri individu tokoh utama.

Pada tokoh A, faktor internal yang menjadi pendorong dinamika kepribadiannya adalah dua macam energi psikis (libido), yaitu (1) dorongan (drive) dan (2) kemauan (will). Dorongan yang menonjol adalah (1) dorongan ingin tahu, (2) dorongan cinta yang meliputi seks, eros, philia, dan agape, dan (3) dorongan keberagamaan, sedangkan kemauan yang menonjol adalah kehendak untuk menjadi diri sendiri. Adanya beberapa bentuk energi psikis tersebut menguatkan pandangan Jung dalam teori psikologi analitis yang menyebutkan bahwa terdapat banyak potensialitas dan aktivitas sebagai wujud dari energi psikis. Hal ini jelas menunjukkan perbedaan mendasar bila 
dibandingkan dengan teori psikoanalitis ortodoks Freud yang menjabarkan teori psikologinya terutama dari satu dorongan saja, yaitu dorongan seks.

Energi psikis itu sendiri bersifat dinamis dan bekerja secara simultan dalam mempengaruhi perkembangan kepribadian A menuju keutuhan pribadi atau realisasi diri. Sifat dinamis dari energi psikis tersebut mengakibatkan timbulnya dinamika kepribadian A sepanjang hidupnya. Adanya dinamika energi psikis yang mempengaruhi dinamika kepribadian A sesuai dengan teori psikologi analitis Jung tentang kepribadian yang mengatakan bahwa adanya energi psikis mengakibatkan kepribadian tidak berhenti atau statis, tetapi selalu dinamis dan terus aktif.

Dorongan ingin tahu dalam diri A berupa desakan alami untuk memuaskan keinginannya yang besar terhadap hal yang baru dan menarik hatinya. Dorongan ingin tahu menimbulkan hasrat A untuk membuktikan tubuh mudanya itu cukup menarik dengan bertanya pendapat Nik meskipun pertanyaan itu dikemas tanpa kegenitan.

Seperti kutipan berikut.

Dan usiaku duapuluh. Usia tatkala manusia baru saja memiliki tubuh mudanya dan penuh dorongan untuk mencoba tubuh yang baru itu.Aku bertanya, tidak dengan genit, kepada Nik: apakah ia mau melakukan itu sebelum menikah. Aku memang betul-betul ingin tahu pendapatnya secara umum, bukan mau mengajaknya sekarang. Untuk urusan itu tak perlu ajak-mengajak. Sebaliknya malah, jika kita tidak menahan diri hal itu pasti akan terjadi dengan sendirinya. Lagipula aku punya banyak waktu lain untuk genit. Dan tanpa genit pun aku tahu tubuh baruku ini menarik. (FI/DIT.4/PEPL/ 31)

Kutipan tersebut menunjukkan betapa besar dorongan ingin tahu A terhadap pendapat Nik tentang tubuh mudanya yang menarik, tubuh muda di usia duapuluh yang menurut A Nik pasti tergoda dan mau melakukan persetubuhan dengannya karena kemenarikan tubuhnya. Keingintahuan A terjawab bahwa Nik tidak akan bersetubuh sebelum menikah dan itu dosa. A juga mulai tahu Nik yang besar dalam keluarga yang konservatif mempunyai pertarungan batin yang hampir sama dengan A tentang persetubuhan.

\section{2) Dorongan Cinta}

Setiap manusia yang hidup bermasyarakat selalu berkembang dan akan mengejar ketertinggalan diri terhadap kemajuan yang terjadi. Perkembangan kepribadian seseorang sangat berpengaruh dalam kelangsungan hidup dalam $(16-28)$ 
bermasyarakat. Salah satu faktor yang mempengaruhi keberhasilan tersebut adalah adanya dorongan cinta dalam diri seseorang. Seperti pemaparan Walgito (2010:16) memaparkan tentang teori dorongan, bahwa setiap organisme memiliki dorongandorongan tertentu yang berkaitan dengan kebutuhan-kebutuhan organisme dan mendorong organisme berperilaku. Bila organisme memiliki kebutuhan dan ingin memenuhi kebutuhannya maka akan terjadi ketegangan dalam diri organisme itu. Bila organisme berperilaku dan dapat memenuhi kebutuhunnya, maka akan terjadi pengurangan atau reduksi dari dorongandorongan tersebut.

Salah satu dorongan yang berkaitan dengan kebutuhan tokoh A yang membuat cerita dalam novel Pengakuaan Eks Parasit Lajang karya Ayu Utami dari awal sampai akhir menjadi sangat menarik adalah dorongan cinta. Dorongan cinta yang terjadi pada tokoh A ada empat jenis, yaitu seks, eros, philia, dan agape. Jenis-jenis dorongan cinta dalam kepribadian tokoh A tersebut sesuai dengan pendapat May, seorang ahli psikologi eksistensial, cinta dapat dikelompokkan ke dalam empat macam, yaitu seks. eros, philia, dan agape (Feist \& Feist, 2014:58-59). Seks adalah fungsi biologis yang dapat dipuaskan melalui hubungan seksual atau cara melepaskan tekanan seksual lainnya. Seks menjadi kekuatan untuk menghasilkan keturunan, dorongan yang dapat mengabadikan suatu ras, sumber kenikmatan paling intens dari manusia sekaligus kecemasan yang paling meresap. Eros adalah hasrat psikologis yang mencari untuk menghasilkan keturunan atau kreasi lewat persatuan dengan seseorang yang dicintai. Eros adalah bercinta, sedangkan seks adalah memanipulasi organorgan. Eros adalah berharap untuk mengukuhkan suatu persatuan yang bertahan lama, sedangkan seks adalah hasrat untuk merasakan kenikmatan. Eros dibangun atas kepedulian dan kelembutan. Oleh karena spesies manusia tidak dapat bertahan tanpa adanya hasrat untuk suatu persatuan yang bertahan lama, maka eros dianggap sebagai penyelamat dari seks. Philia adalah hubungan pertemanan yang intim di antara dua orang, namun nonseksual. Eros dibangun dengan landasan philia. Philia membutuhkan waktu untuk tumbuh, berkembang, dan mengakar. Philia tidak menuntut kita untuk berbuat apa-apa pada orang yang kita cintai, selain menerimanya, mendampinginya, dan menikmati bersamanya. Bentuk cinta yang terakhir adalah agape, yaitu penghargaan untuk orang lain atau kepedulian atas 
kesejahteraan orang lain yang melebihi keuntungan apa pun yang dapat diperoleh seseorang dari hal tersebut. Agape adalah cinta yang tidak terkecuali, seperti cinta Tuhan pada manusia.

Dorongan cinta sangat berpengaruh terhadap dinamika kepribadian A. Cinta dapat dikatakan hampir merangkum keseluruhan gagasan isi novel Pengakuan Eks Parasit Lajang. Inilah nampaknya salah satu alasan pengarang memberi judul tersebut karena cerita yang dipaparkan merupakan pengakuan pengarang tentang dirinya dalam menjalani hidup yang diawali dengan perjalanan cinta A dari dorongan cinta yang sederhana sampai dorongan cinta yang kompleks.

Dorongan cinta dalam diri A menimbulkan hasrat mencintai baik terhadap lawan jenis maupun sesama manusia. Hasrat mencintai menggerakkan perilaku mencintai yang berwujud cinta seks, eros, dan philia pada lawan jenis dan cinta agape pada keluarga, kaum kerabat, sahabat, dan sesama manusia. Dorongan cinta tersebut pada akhirnya membentuk kepribadian A yang penuh cinta kasih dan kepedulian pada sesama.

Aku mulai merindukan Dan. Perlahan tapi pasti aku jatuh cinta padanya. Aku tidak ingin memanjang-manjangkan cerita romantis, atau meromantisir drama di bagian ini. Pendek kata, dalam tahun kedua persahabatan kami yang intim itu, akhirnya kami bercinta. Dialah satu-satunya pria yang dengannya aku bersetubuh setelah menyayanginya. Dengan semua lelaki yang lain, rasa sayang itu baru datang belakangan, setelah kami sering bersetubuh. Tapi, itu juga pertama kalinya aku bercinta dengan suami orang. Itu merupakan titik perubahan besar dalam hidupku...(FI/DC. /PEPL/72)

..."Maksudnya?"

tanyaku. Sungguh mati, waktu itu aku belum pernah bertemu orang yang secara terangterangan mendukung poligami. Aku masih muda dan tidak berpengalaman. Agaknya dialah orang pertama yang kukenal.

Aku tak suka jawabannya. Aku merasa ada yang tidak adil dalam pikirannya. Kubilang padanya, "Tuhan kan sangat kuat. Sakit hatinya tak akan seberapa. Tapi kalau kamu menikah lagi, istri kamu yang kamu sakiti secara sah."

Kalau aku, aku lebih
memilih menyakiti hati pihak
(16-28) 
yang kuat daripada menyakiti pihak yang lemah. Jika aku melukai yang lemah, itu berarti aku sewenang-wenang. (FI/DC. /PEPL/77)

Kedua kutipan di atas menunjukkan kepribadian A yang penuh cinta kasih kepada kekasihnya yang bernama Dan dan kepeduliaanya terhadap sesama, para istri yang sah. A tidak menyetujui poligami karena akan menyakiti pihak yang lemah yaitu perempuan. Jika A menyakiti yang lemah berarti dia sewenangwenang.

Dorongan cinta dalam diri A bersifat dinamis, yaitu mengalami pendewasaan seiring bertambahnya usia. Pada awalnya dorongan cinta yang muncul berjenis cinta seks pada lawan jenis pada masa pubertas hingga akhir masa remaja. Bentuk cinta seks berkembang menjadi hubungan yang lebih intim, yaitu cinta jenis philia pada masa-masa kuliah A. Cinta seks akhirnya mencapai bentuk cinta eros setelah A akhirnya menikah, meskipun A merasa pamahamannya tentang eros terlambat kerana sebelumnya telah terjerumus pada zina. Cinta seksual menjadi sumber permasalahan yang dihadapi A dalam perjalanan hidup selanjutnya.

\section{3) Dorongan Kerja}

Faktor internal yang menjadi pendorong dinamika kepribadian A selain dorongan cinta yakni dorongan kerja. Dorongan kerja pada tiap-tiap pribadi berbedabeda. Dorongan kerja pada diri A sangat kuat pengaruhnya terhadap perkembangan pribadi A dalam perjalanan hidupnya. Keberhasilan kerja A karena dorongan kerja tersebut menimbulkan hasrat bekerja dalam diri A yang aktif dan kreatif.

Aku masih kuliah. Tapi aku juga sudah mencoba kerja sebagai sekretaris di sebuah kantor pemasok keperluan angkatan bersenjata, di daerah Krekot Bunder. Aku mencari kerja sebab aku mulai tahu mutu pengetahuan yang kudapat di Jurusan Sastra Rusia Fakultas Sastra Universitas Indonesia masa itu. (FI/DK.1/PEPL/50)

Aku hanya berkecimpung sebentar saja di dunia model. Aku merasa tak cocok dengan pergaulan di sana. Tak lama setelah itu, aku menjadi wartawan. Pekerjaan ini lebih mendekatkan aku pada dunia pemikiran. Di dunia baru ini orang-orang mewartakan mereka yang tolol dan miskin pengetahuan.

(FI/DK.2/PEPL/62)

A bekerja sebagai
jurnalis di sebuah majalah
berita. Pada masa itu,
wartawati belum banyak.
Barangkali satu banding empat
$(16-28)$ 
dengan

wartawan. (FI/DK.3/PEPL)

Kutipan-kutipan tersebut menunjukkan hasrat kerja A tertuju pada satu tujuan konkrit yaitu terpenuhi kecenderungan yang timbul dalam pribadi A. Hasrat kerja A selalu muncul berulangulang untuk selalu mencari profesi yang cocok dengan pribadinya. Hasrat dan kecenderungan selalu beriringan untuk menghasilkan kerja yang bagus.

\section{4) Kemauan}

Kemauan dalam diri A berupa kehendak menjadi diri sendiri. Kemauan menggerakkan perilaku yang selalu berusaha untuk mewujudkan obsesinya membangun horminisasi antara kejujuran pribadi dengan kejujuran dalam nilai-nilai agama A serta menggapai tujuan hidupnya yang dibangun dengan teorinya sendiri. Sebagai manusia A memiliki kemauan yang selalu didasari kesadaran pribadi karena dalam novel ini A mewakili pengarang mengungkapkan pengakuan hidup yang telah dijalani selama kurun waktu dari masa kecil, masa kuliah sampai ketika A memutuskan keinginan tidak akan menikah kemudian dengan segala pertimbangan akhirnya A menikah meski hanya menikah secara agama. Komitmen tersebut menimbulkan penilaian bermacam-macam terhadap A. Ada yang menilai A lesbi dan segala macam penilaian negatif tertuju padanya. A tetap pada kemauannya sendiri yang penting menurut dia apa yang diputuskan dan dijalani tidak menodai kesucian nilai kejujuran agama. Karena itu A menjauh dari agama. Meskipun menjauhi agama A tetap menghormati nilai-nilai agama dan sebagai manusia $\mathrm{A}$ juga masih percaya adanya dosa karena bagaimanapun A tumbuh dalam keluarga yang taat beragama. Kemauan A merupakan dorongan kehendak yang terarah pada satu tujuan hidup yaitu ingin jadi diri sendiri dalam merealisasikan prinsip hidupnya yang telah dia pelajari di bangku kuliah juga dari Alkitab yang ikut membentuk dunianya.

Berkaitan dengan kemauan A tersebut diperkuat oleh beberapa pendapat yaitu, sebagai anima intelektiva, menurut Aristoteles, manusia di samping memiliki kemampuan seperti tumbuhan dan hewan masih mempunyai kemampuan lain yaitu berpikir dan berkemauan (Walgito, 2010:7). Kemauan (will) atau kehendak adalah fungsi yang terlibat dalam perbuatan yang disadari (Chaplin, 2011:539). Kemauan (will) adalah dorongan kehendak yang terarah pada tujuan-tujuan hidup tertentu dan dikendalikan oleh pertimbangan akal budi. Kemauan (16-28) 
mengakibatkan timbulnya dinamika dan aktivitas manusia yang diarahkan pada pencapaian tujuan akhir. Kemauan merupakan dorongan pada setiap manusia untuk merealisasikan diri, dalam pengertian mengembangkan segenap bakat dan kemampuannya serta meningkatkan taraf kehidupan. Jelasnya, dengan kemauan kuat diri sendiri dijadikan "proyek" untuk dibangun dan diselesaikan sesuai dengan gambaran ideal tertentu.

Sekarang aku telah
memiliki tata moralku yang
mandiri, kubangun ulang dari
sistem-sistem yang diperkenalkan
kepadaku tapi dengan rasa
keadilanku yang spesifik. Nik
tidak. la masih sepenuhnya
menggunakan sistem yang
diberikan kepadanya oleh
pihak lain. (Tentu saja, sistem
itu menguntungkan lelaki. Jadi
untuk apa ia berpikir kritis?)
(FI/KDS.1/PEPL/37)

Aku tidak mau menerima nilai-nilai yang menurutku tidak adil. Tak ada yang bisa menjawabku di mana letak keadilan dalam hal memuliakan dan menuntut keperawanan wanita. Karena itu, pelan-pelan aku mencoret ayat ini dalam tata moralitasku sendiri. Untunglah agama tidak pernah menjadikan keperawanan sebagai syarat perkawinan pertama.
(FI/KDS.2/PEPL/35)

Kutipan tersebut menunjukkan betapa kuatnya kemauan untuk menjadi diri sendiri dalam diri A. Kemauan tersebut menjadi pendorong dinamika kepribadian A dalam berpikir contohnya A tetap dengan nilai-nilai keadilannya sendiri meskipun Nik pernah ingin mengubah imannya tetapi dia tetap pada imannya walaupun A menicintai Nik. A tidak mau mengorbankan nilai-nilai yang dibangun sendiri hanya demi cinta. Dorongan kemuauan ini menjadikan sosok A kuat tegas dalam mencapai tujuan hidupnya. Ketegasan prinsip terhadap keperawanan A cukup kuat.

\section{Faktor-faktor Eksternal Pendorong Dinamika Kepribadian Tokoh Utama}

Faktor eksternal merupakan faktor yang yang berasal dari luar individu yang mempengaruhi dinamika kepribadian, yaitu lingkungan. Menurut Walgito (2010:55) lingkungan mempunyai peranan yang penting dalam perkembangan individu. Faktor lingkungan dapat dikelompokkan dalam dua kategori, yaitu (1) lingkungan fisik yang berupa alam, dan (2) lingkungan sosial atau masyarakat. Di dalam masyarakat terdapat interaksi antara individu yang satu dengan yang lainnya. Lingkungan sosiai itu sendiri dapat 
dibedakan ke dalam dua kelompok, yaitu (1) lingkungan sosial primer, dimana terdapat hubungan yang erat antara anggota yang satu dengan anggota lain, sehingga pengaruhnya terhadap perkembangan individu akan lebih mendalam, dan (2) lingkungan sosial sekunder, dimana hubungan antar anggotanya agak longgar, kurang atau tidak saling kenal mengenal.

Dalam penelitian ini faktor-faktor eksternal pendorong dinamika kepribadian tokoh utama yang dibahas adalah lingkungan sosial primer yang berhubungan dengan figur keluarga dan figur teman dekat A.

\section{SIMPULAN}

Berdasarkan data yang telah dideskripsikan dan dianalisis, maka peneliti dapat menarik kesimpulan bahwa ditemukan adanya data-data yang mencerminkan dinamika kepribadian tokoh utama dalam novel Pengakuan Eks Parasit Lajang Karya Ayu Utami yang sesuai dengan perspektif Jung, sebagai berikut.

(1) Faktor-Faktor

Internal

Pendorong Dinamika Kepribadian Tokoh Utama

Faktor internal yang menjadi pendorong dinamika kepribadian tokoh utama adalah energi psikis (libido) berupa dorongan (drive) dan kemauan (will) yang bersifat dinamis dan bekerja secara simultan menuju keutuhan pribadi. Dorongan meliputi (1) dorongan ingin tahu yang menimbulkan hasrat mencari ilmu dan membentuk kepribadian yang berpengetahuan luas dan tegas, (2) dorongan cinta yang menimbulkan hasrat untuk mencintai berupa cinta seks, eros, philia, dan agape dan membentuk kepribadian yang penuh cinta kasih dan kepedulian pada sesama. Sedangkan kemauan berupa kehendak menjadi diri sendiri yang memunculkan obsesi dan membentuk kepribadian yang penuh motivasi pada tujuan hidup.

(2) Faktor-Faktor

Ekternal Pendorong Dinamika Kepribadian Tokoh Utama

Faktor eksternal yang menjadi pendorong dinamika kepribadian tokoh utama adalah lingkungan sosial tokoh utama terutama faktor lingkungan sosial primer yaitu figur keluarga. Figur keluarga membentuk kepribadian tokoh utama yang cenderung keras, tegas, penuh cinta juga peduli pada sesama dalam menjalani hidup. Kepribadian tokoh utama yang keras dan tegas dipengaruhi dari figur ayah dan kepribadian yang penuh cinta kasih, peduli pada sesama dipengaruh oleh figur ibu. $(16-28)$ 
DAFTAR PUSTAKA

Chaplin, J.R. 2011. Kamus Lengkap Psikologi. Terjemahan Kartini Kartono.

Depok: Rajagrafindo Persada.

Feist, J. \& Feist, G. J. 2014. Teori Kepribadian, Edisi 7 (Buku 1). Terjemahan Handriatno. Jakarta: Salemba Humanika.

Purba, A. 2010. Sastra Indonesia Kontemporer. Yogyakarta: Graha Ilmu.

Ratna, N. K. 2013. Teori, Metode, dan Teknik Penelitian Sastra.
Yogyakarta: Pustaka Pelajar.

Santana, S. 2010. Menulis Ilmiah: Metodologi Penelitian Kualitatif. Jakarta: Yayasan Pustaka Obor Indonesia.

Walgito, B. 2010. Pengantar Psikologi Umum. Yogyakarta: Andi Offset.

Wellek, Rene $\mathcal{E}$ Warren, A. 2014. Teori Kesusastraan. Terjemahan Melani Budianta. Jakarta: Gramedia. 